\title{
Kako steći predodžbu o veličini atoma i iona
}

\section{Sikirica *}

Zavod za opću i anorgansku kemiju, Kemijski odsjek, Prirodoslovno-matematički fakultet, Horvatovac 102A, HR-10 000 Zagreb

\section{Sažetak}

U kemiji i nastavi kemije rabe se veličine pikometar i Avogadrov broj. Nastavnici lakoćom izgovore ili napišu, a učenici napamet nauče i reproduciraju te veličine, bez predodžbe o tomu koliko je $10^{-12}$ ili $10^{23}$. U ovom je radu pokazano kako vlastitom aktivnošću, u ovom slučaju rješavanjem jednostavnih problemskih zadataka iz područja strukturne kemije, učenici mogu samostalno doći do spoznaja o veličini atoma i usporediti ih s veličinama poznatih makro objekata. Time bi se spriječilo učenje napamet o veličinama čestica fundamentalno važnih u području nastave prirodnih znanosti. U ovo digitalno doba uz "nastavu na daljinu" i digitalizirane udžbenike suvremena škola ne treba tiskane udžbenike i "razrede", već laboratorije i radionice te sportske dvorane i sportske terene gdje će učenici znanja, vještine i sposobnosti stjecati vlastitom aktivnošću.

Ključne riječi

Nastava kemije, HCP i FCC kristalne strukture, atomski i ionski radijusi, intersticijske šupljine, riješeni ispitni zadatci

\section{Uvod}

Atom, atomska energija, atomska fizika, atomska bomba, atomska podmornica, atomska velesila i dr. pojmovi su koje susrećemo u svakodnevnom govoru, ali i u nastavnim programima osnovnih škola. Primjerice, u Odluci o donošenju kurikuluma za nastavni predmet kemija za osnovne škole i gimnazije u Republici Hrvatskoj (NN 10/2019-208) pod Odgojno-obrazovni ishodi u 7. razredu osnovne škole stoji:

Navodi definicije atoma, kemijskoga elementa, izotopa i elementarne tvari. Opisuje građu atoma. Razlikuje protonski od nukleonskog broja. Opisuje strukturu periodnoga sustava elemenata. Piše simbole kemijskih elemenata prvih četiriju perioda te $\mathrm{Au}, \mathrm{Ag}, \mathrm{Hg}, \mathrm{Pb}$ i I.

Ipak, postavlja se pitanje što djeca, učenici, a i obični građani razumiju pod navedenim pojmovima. Primjerice, u Kemija 7 - Digitalni obrazovni sadržaji za sedmi razred osnovne škole za predmet kemija ${ }^{1}$ u modulu 3.1. Građa atoma, možemo pročitati:

Atomi su tako male čestice da bi na duljinu $1 \mathrm{~mm}$ stala čak 2000000 atoma željeza. lako modele atome često prikazujemo kao kuglice ili kalote, važno je naglasiti da atomi nemaju čvrste $i$ oštre granice.

(Op. autora: Kuglica nije kalota. Kalote se rabe za prikazivanje građe molekula.)

* Prof. dr. sc. Milan Sikirica

e-pošta: sikiricamilemilan@gmail.com
U nastavi kemije atomi se obično prikazuju kuglicama čiji se radijus izražava u pikometrima. Prisjetimo se da je pikometar $10^{-12} \mathrm{~m}$. Kad se govori o količini tvari, rabi se jedinica mol. ${ }^{2}$ Jedan mol sadržava točno $6,02214076 \cdot 10^{23}$ atoma, iona, molekula ili drugih definiranih jedinki. Nastavnici će lakoćom izgovoriti ili napisati, a učenici napamet naučiti i reproducirati navedene brojeve bez mnogo razmišljanja ili predodžbe o tomu koliko je $10^{-12}$ ili $10^{23}$. Zato ću u ovom prikazu navedene brojeve pokušati približiti spoznajama iz svakodnevnog života. Na temelju podataka dostupnih na internetu pokazat ću kako se mogu izračunati atomski i ionski radijusi elemenata I. i II. skupine periodnog sustava elemenata. Za to su dostatna znanja stečena već u osnovnoj školi.

Kemija je eksperimentalna znanost, ali u školama je sve manje eksperimenata, a sve više učenja napamet, tj. bubanja. Tomu pridonose aktualni nastavni programi i "nastava na daljinu" uzrokovana virusom COVID-19. No ne smijemo zaboraviti da se pokusima koje izvode učenici razvijaju vještine te uči promatrati i donositi zaključke na temelju rezultata opažanja ili mjerenja. Umjesto učenja napamet do istog "znanja" učenici mogu sami doći izvođenjem pokusa ili rješavanjem primjerenih zadataka. Uz nastavu na daljinu, digitalizirane udžbenike i druge digitalizirane nastavne materijale, suvremena škola ne treba "razrede" u kojima će učenici sjediti "u potiljak" a nastavnici docirati. Suvremena škola treba laboratorije, radionice, sportske dvorane ali i sportske terene, gdje će učenici znanja, vještine i sposobnosti stjecati vlastitom aktivnošću. 


\section{Edukacijske aktivnosti}

Svatko ima jasnu predodžbu o tome kolika je duljina $1 \mathrm{~mm}$. Predodžbu o tome koliko je dva milijuna,, primjerice atoma, kuna ili još bolje eura, učenici 7 . razreda osnovne škole mogu steći brojenjem. Učenicima se može zadati da izračunaju koliko bi im dana trebalo da izbroje 2 milijuna kuna, ako svake sekunde odbroje jednu kunu. To će izračunati tako da 2 milijuna sekunda podjele brojem sekundi u jednom danu.

$$
\frac{2000000 \mathrm{~s}}{60 \mathrm{~s} \mathrm{~min} \mathrm{~min}^{-1} \cdot 60 \mathrm{~min} \mathrm{~h}^{-1} \cdot 24 \mathrm{~h} \mathrm{dan}^{-1}}=23,15 \text { dan }
$$

Kako kovanica od 1 kune ima masu 5 g, proizlazi da 2 milijuna kovanica od jedne kune ima masu 10 milijuna grama, tj. 10 tona (= pun šleper kovanica). Teško je biti milijunaš. Za razliku od običnih ljudi milijunaš nema vremena ni prebrojiti svoj novac a, osim toga, gdje će "na sigurno" pohraniti 10 tona kuna?

Kad smo već kod kovanica, mogli bismo učenicima zadati da izračunaju koliko atoma sadržava kovanica od 1 kune. Taj i neki naredni zadatci primjereni su učenicima prvog razreda srednjih škola nakon što usvoje pojmove: maseni udio, mol, molni udio i Avogadrova konstanta, $N_{\mathrm{A}}=6,02214076 \cdot 10^{23} \mathrm{~mol}^{-1}$.

Primjer 1. Izračunajte broj atoma u kovanici od 1 kune mase 5 g izrađene od slitine koja sadržava $65 \%$ bakra $(\mathrm{Cu})$, $23,2 \%$ nikla (Ni) i $11,8 \%$ cinka (Zn).

$$
\begin{aligned}
N(\text { atoma })= & N_{\mathrm{A}} \cdot\left(\frac{m(\mathrm{Cu})}{M(\mathrm{Cu})}+\frac{m(\mathrm{Ni})}{M(\mathrm{Ni})}+\frac{m(\mathrm{Zn})}{M(\mathrm{Zn})}\right) \\
N(\text { atoma }) & =6,022 \cdot 10^{23} \mathrm{~mol}^{-1} \cdot \\
\cdot\left(\frac{3,250 \mathrm{~g}}{63,55 \mathrm{gol}^{-1}}+\frac{1,160 \mathrm{~g}}{58,70 \mathrm{gol}^{-1}}+\frac{0,590 \mathrm{~g}}{65,38 \mathrm{~g} \mathrm{~mol}^{-1}}\right) & \\
N(\text { atoma })= & 6,022 \cdot 10^{23} \mathrm{~mol}^{-1} \cdot \\
& \cdot\left(0,0511 \mathrm{~mol}^{2} 0,0198 \mathrm{~mol}+0,0090 \mathrm{~mol}\right) \\
N(\text { atoma })= & 6,022 \cdot 10^{23} \mathrm{~mol}^{-1} \cdot 0,0799 \mathrm{~mol}=4,812 \cdot 10^{22}
\end{aligned}
$$

Učenici će lako upamtiti i napisati Avogadrov broj ili izračunati broj atoma u kovanici od jedne kune, ali jesu li svjesni veličine tih brojeva? Zato je prikladno zatražiti da učenici najprije procijene a potom izračunaju koliko bi vremena 7,8 milijarda ljudi brojilo jedan mol atoma ili broj atoma u kovanici od jedne kune kad bi svaki čovjek svake sekunde odbrojio jedan atom.

Ako je točan podatak o tome da na duljinu od $1 \mathrm{~mm}$ stane 2000000 atoma željeza, proizlazi da je dijametar atoma željeza:

\footnotetext{
"Koliko je teško steći predodžbu o velikim brojevima, vidi se i iz povijesti: najveći broj koji je za stare Rimljane imao ime bila je tisuća, a za Grke deset tisuća (mirijada). U našem narodu broj koji u prenesenom značenju znači „mnogo“ je stotina, a kod Arapa taj broj iznosi samo sedam.
}

$$
d=\frac{10^{-3} \mathrm{~m}}{2 \cdot 10^{6}}=0,5 \cdot 10^{-9} \mathrm{~m}=500 \mathrm{pm}
$$

Uobičajeno je veličinu atoma iskazivati atomskim radijusom, pa proizlazi da je radijus atoma željeza $250 \mathrm{pm}$. U tablici atomskih radijusa metala ${ }^{3}$ za atomski radijus željeza navodi se 127 pm, natrija 121 pm, kalija 238 pm, rubidija 253 pm, a najveći atomski radijus, 270 pm, ima cezij. U nekoj drugoj tablici naći ćemo malo drugačije podatke za atomske radijuse istih kemijskih elemenata. To se događa zato što autori pojedinih tablica pri izračunavanju radijusa uzimaju u obzir različito okruženje (koordinaciju) atoma u kristalnim strukturama. Pokušajmo sami izračunati radijus atoma željeza. Pretpostavimo da su atomi krute kuglice koje se u kristalnoj strukturi čistog željeza međusobno dotiču. No najprije se moramo vratiti u 19. stoljeće ili još ranije.

\section{Guste slagaline}

Uzmimo da su atomi kuglice kao što je u knjizi Novi sustav kemijske filozofije (engl. New System of Chemical Philosophy, I, 1808., II, 1810.). predvidio engleski prirodoslovac, kemičar i fizičar John Dalton (1776. - 1844.). ${ }^{4}$ Slagalinama kuglica jednake veličine bavio se njemački matematičar i astrolog Johannes Kepler (1571. - 1611.) ${ }^{5}$ te je još 1611. god. naslutio (Kepler conjecture) da se kuglice jednake veličine mogu najgušće složiti na dva načina, kao heksagonska i kubna gusta slagalina. U oba načina slaganja samo je $74,05 \%$ prostora zaposjednuto kuglicama.
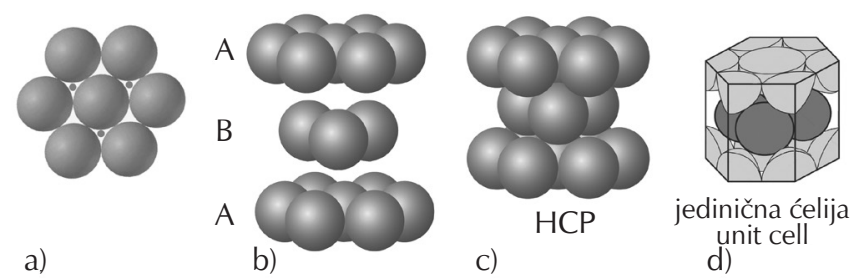

Slika 1 - Heksagonska gusta slagalina kuglica jednake veličine Fig. 1 - Hexagonal Closest Packed Structure, HCP

Pri pokušaju najgušćeg slaganja kuglica jednake veličine dobit ćemo sloj u kojem je svaka kuglica okružena sa šest kuglica na jednakoj udaljenosti, kao na slici 1a. Pritom oko svake kuglice nastaje šest tzv. trokutnih šupljina, od kojih su tri iz didaktičkih razloga označene točkom. Kuglice sljedećeg sloja (B) sjedaju u udubljenja, označena točkom, koje čine tri kuglice prvoga sloja (A). Ako je sljedeći tj. treći sloj jednak prvom, tad se dobivena slagalina može opisati heksagonskom prizmom (engl. Hexagonal Closest Packed Structure, HCP) kao na slikama 1c i 1d. U strukturi HCP slojevi se slažu jedan povrh drugoga redoslijedom $A B A B$ itd. ${ }^{6}$ Tako kristaliziraju primjerice $\mathrm{Mg}$, Sc, Ti, Co, Zn, Cd i neki drugi metali. ${ }^{7}$ Pritom je svaka kuglica (atom) okružena s 12 istovrsnih kuglica na jednakoj udaljenosti. Broj atoma koji okružuju neki atom na jednakoj udaljenosti naziva se koordinacijskim brojem, KB, pa je u HCP kristalnim strukturama $\mathrm{KB}=12$. 

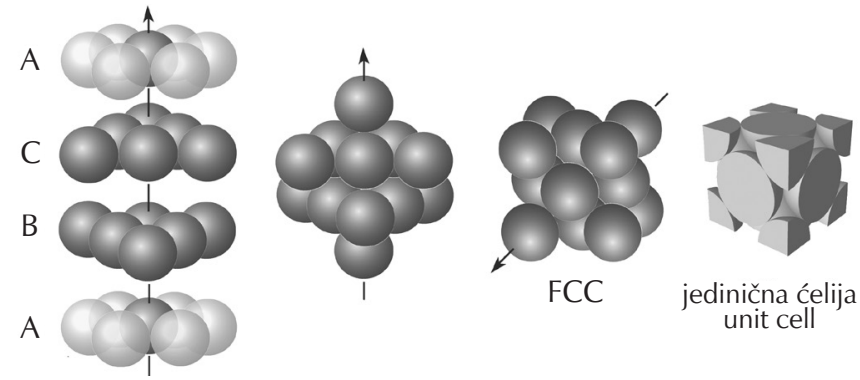

Slika 2 - Plošno centrirana kocka

Fig. 2 - Face Centered Cubic Structure, FCC

Kad se kuglice trećeg sloja (C) smjeste iznad onih udubljenja koja u prvom sloju (A) nisu bila zaposjednuta kuglicama drugog sloja (B), tad se dobije gusta kubna slagalina, ${ }^{6}$ koju opisujemo plošno centriranom kockom (engl. Face Centered Cubic Structure, FCC) kao na slici 2. Tako kristaliziraju $\mathrm{Al}, \mathrm{Ca}, \mathrm{Ni}, \mathrm{Cu}, \mathrm{Ag}, \mathrm{Au}, \mathrm{Pb}$ i neki drugi metali te svi plemeniti plinovi, osim helija, koji ima kristalnu strukturu HCP. U FCC strukturi slojevi se slažu jedan povrh drugoga redoslijedom ABCABC itd. Svaka je kuglica okružena s 12 istovrsnih kuglica na jednakoj udaljenosti, pa je za FCC kristalne strukture $K B=12$. Jedinična ćelija sadržava 4 atoma jer atomi na središtima ploha samo jednom polovinom, a oni na vrhovima samo jednom osminom pripadaju kocki $(6 \cdot 1 / 2+8 \cdot 1 / 8=4)$. Pod jediničnom ćelijom razumije se najmanji dio kristalne strukture koji se periodički ponavlja u sva tri smjera u prostoru.

Modele heksagonske i kubne guste slagaline učenici mogu sami načiniti od kuglica za božićno drvce ili stiroporskih kuglica koje mogu nabaviti u trgovinama materijala za hobby. Učenicima se može zadati da nacrtaju jediničnu ćeliju FCC kristalne strukture, izračunaju broj atoma u jediničnoj ćeliji, izračunaju gustoću pakiranja te provjere Keplerovu slutnju da je $74,05 \%$ prostora zaposjednuto kuglicama.

\section{Atomski (metalni) radijusi}

Ostali smo u nedoumici koliki je stvarni radijus atoma željeza, tj. koliko atoma željeza stane na duljinu od $1 \mathrm{~mm}$. No prije svega moramo nešto naučiti o kristalnoj strukturi željeza. Ovisno o temperaturi željezo se javlja u tri kristalne modifikacije kao alfa-željezo, gama-željezo i delta-željezo. Pri sobnoj temperaturi pa sve do $914{ }^{\circ} \mathrm{C}$ stabilno je $\alpha$-željezo koje ima kristalnu strukturu prostorno centrirane kocke (engl. Body Centered Cubic Structure, BCC) prikazane na slici 3. Pri temperaturi od $914{ }^{\circ} \mathrm{C}$ do $1391{ }^{\circ} \mathrm{C}$ stabilno je $\gamma$-željezo koje ima FCC kristalnu strukturu (plošno centrirana kocka) kao na slici 2. Iznad $1391{ }^{\circ} \mathrm{C}$ pa sve do tališta, $1538{ }^{\circ} \mathrm{C}$, stabilno je $\delta$-željezo s BCC kristalnom strukturom.

U BCC kristalnoj strukturi atomi se dotiču smjerom prostorne dijagonale kocke. Svaki je atom okružen s 8 istovrsnih atoma, pa je u BCC strukturi $K B=8$. Jedinična ćelija sadržava 2 atoma jer atomi na uglovima kocke samo $1 / 8$ pripadaju jediničnoj ćeliji.
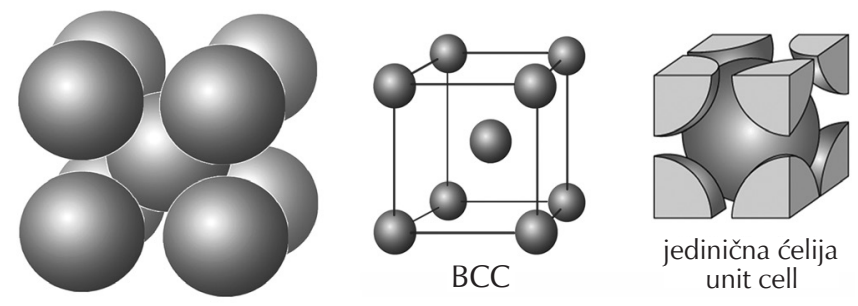

jedinična ćelija unit cell

Slika 3 - Prostorno centrirana kocka

Fig. 3 - Body Centered Cubic Structure, BCC

Prostorno centrirana kocka, BCC, nije najgušća slagalina kuglica jednake veličine. Gustoću pakiranja (engl. packing density) izračunat ćemo tako da volumen dviju kuglica podijelimo volumenom kocke. Uzmemo li da je brid kocke a, tad je radijus kuglice (atoma) u BCC kristalnoj strukturi jednak četvrtini prostorne dijagonale kocke, tj. $r($ atom $)=a \frac{\sqrt{ } 3}{4}$. Odavde proizlazi:

$$
\begin{aligned}
\text { gustoća pakiranja } & =\frac{2 \cdot \frac{4}{3} r^{3} \pi}{a^{3}}=\frac{2 \cdot \frac{4}{3}\left(\frac{a \sqrt{ } 3}{4}\right)^{3} \pi}{a^{3}}= \\
& =\frac{\pi \sqrt{3}}{8}=0,680 \text { ili } 68 \%
\end{aligned}
$$

Primjer 2. Da bismo izračunali atomski (metalni) radijus $\alpha$-željeza, $r(\alpha-\mathrm{Fe})$, moramo znati volumen kocke koja sadržava dva atoma željeza. To se može izračunati na temelju poznatih veličina: gustoće, molarne mase i Avogadrove konstante, gdje je $\rho(\mathrm{Fe})=7,874 \mathrm{~g} \mathrm{~cm}^{-3}, M(\mathrm{Fe})=55,845 \mathrm{~g} \mathrm{~mol}^{-1}$ i $N_{\mathrm{A}}=6,02214076 \cdot 10^{23} \mathrm{~mol}^{-1}$. Za volumen kocke koja sadržava 2 atoma željeza dobivamo:

$$
\begin{gathered}
V(2 \mathrm{Fe})=\frac{2 \mathrm{M}(\mathrm{Fe}) / \mathrm{N}_{\mathrm{A}}}{\rho(\mathrm{Fe})} \\
V(2 \mathrm{Fe})=\frac{\frac{2 \cdot 55,845 \mathrm{~g} \mathrm{~mol}^{-1}}{6,022 \cdot 10^{23} \mathrm{~mol}^{-1}}}{7,874 \mathrm{~g} \mathrm{~cm}^{-3}}=23,555 \cdot 10^{-24} \mathrm{~cm}^{3}
\end{gathered}
$$

Odavde proizlazi da je brid jedinične ćelije $\alpha$-željeza:

$$
a=\sqrt[3]{23,555 \cdot 10^{-24} \mathrm{~cm}^{3}}=2,866 \cdot 10^{-8} \mathrm{~cm}=286,6 \mathrm{pm}
$$

Za atomski (metalni) radijus $\alpha$-željeza, $r(\alpha-\mathrm{Fe})$, dobivamo:

$r(\alpha-\mathrm{Fe})=\frac{a \sqrt{3}}{4}=\frac{2,866 \cdot 10^{-8} \mathrm{~cm} \cdot \sqrt{3}}{4}=1,241 \cdot 10^{-8} \mathrm{~cm} \approx 124 \mathrm{pm}$

No brid jedinične ćelije $\alpha$-željeza može se neposredno izmjeriti difrakcijom rendgenskih zraka poznate valne duljine. Tako je za brid jedinične ćelije $\alpha$-željeza pri sobnoj temperaturi izmjereno: $a(\alpha-\mathrm{Fe})=286,65 \mathrm{pm}^{8,9}$ Odavde proizlazi da je atomski (metalni) radijus $\alpha$-željeza: 


$$
r(\alpha-\mathrm{Fe})=\frac{\mathrm{a} \sqrt{3}}{4}=\frac{286,65 \mathrm{pm} \cdot \sqrt{3}}{4} \approx 124 \mathrm{pm}
$$

Dvjema različitim metodama dobili smo jednake vrijednosti metalnog radijusa $\alpha$-Fe, pa možemo zaključiti da oko 4 milijuna atoma željeza čine lančić (niz, nisku) duljine $1 \mathrm{~mm}$.

Već smo kazali da gama-željezo ima FCC kristalnu strukturu. Difrakcijom rendgenskih zraka nađeno je da je brid jedinične ćelije: $a(\gamma-\mathrm{Fe})=359 \mathrm{pm} .{ }^{9} \mathrm{U}$ FCC kristalnoj strukturi atomi se dotiču smjerom plošne dijagonale kocke, pa proizlazi da je metalni radijus $\gamma$-željeza:

$$
r(\gamma-\mathrm{Fe})=\frac{a \sqrt{ } 2}{4}=\frac{359 \mathrm{pm} \cdot \sqrt{ } 2}{4} \approx 127 \mathrm{pm}
$$

Metalni radijus željeza u FCC strukturi malo je veći od radijusa u BCC strukturi. To se događa zato što je u $\alpha$-Fe svaki atom okružen s 8, a u $\gamma$-Fe s 12 istovrsnih atoma. Dobivena vrijednost metalnog radijusa željeza podudara se s podatkom iz tablice atomskih radijusa. ${ }^{3}$

Sada je trenutak kad se učenicima može zadati da izračunaju duljinu lančića koji čini mol atoma željeza ili da izračunaju masu lančića od atoma željeza koji bi sezao od Zemlje do Mjeseca.

Prikladan je zadatak i izračunati površinu monoatomnog sloja koji tvori jedan mol atoma, primjerice aluminija, čiji je metalni radijus $r(\mathrm{Al})=125 \mathrm{pm}$. (Pomno proučite sliku 1a!) Naime, u suvremenoj proizvodnji poluvodiča, solarnih panela, alata, optičkih pribora i dr. prevlake od tankih slojeva (engl. thin films) debljine nekoliko nanometara na krutim površinama dobiju se naparavanjem u vakuumu. Naparavanje se izvodi fizičkim (engl. physical vapour deposition, PVD) ili kemijskim postupcima (engl. chemical vapor deposition, CVD). Tanke filmove aluminija možemo vidjeti na "celofanu" kojim cvjećari zamataju cvijeće i na metaliziranoj plastičnoj ambalaži. Leće naočala zaštićuju se naparavanjem tankog sloja $\mathrm{SiO}_{2}, \mathrm{Si}_{3} \mathrm{~N}_{4}, \mathrm{TiO}_{2} \mathrm{i} \mathrm{dr}$.

U nastavku ćemo riješiti još nekoliko zadataka (primjera) u svezi s kristalnim strukturama i metalnim radijusima atoma izraženim u pm, tj. $10^{-12} \mathrm{~m}$. Pikometar je nezamislivo mala veličina, $10^{12}$ puta manja od metra. Bolje razumijevanje tog odnosa može se steći ako se promjer Sunca, 1392000 km, predoči $10^{12}$ puta manjom kuglicom. Rezultati će iznenaditi svakoga, ali će pridonijeti boljem razumijevanju sitnoće atoma. Osim toga, to je dobra vježba za pretvaranje jednih mjernih jedinica u druge.

Primjer 3. Kristalnu strukturu bakra opisujemo plošno centriranom kockom, FCC. Pri $100{ }^{\circ} \mathrm{C}$ jedinična ćelija bakra ima brid $a=361,47$ pm. Izračunajte metalni radijus i gustoću bakra pri $100{ }^{\circ} \mathrm{C}$.

\section{Rješenje}

Jedinična ćelija sadržava 4 atoma koji se dotiču smjerom plošne dijagonale kocke. Metalni radijus bakra pri $100{ }^{\circ} \mathrm{C}$ jednak je:

$$
r(\mathrm{Cu})=\frac{\mathrm{a} \sqrt{2}}{4}=\frac{361,47 \mathrm{pm} \cdot \sqrt{2}}{4}=127,8 \mathrm{pm}
$$

Gustoća tvari jednaka je omjeru mase i volumena. Molarna masa bakra je 63,55 $\mathrm{g} \mathrm{mol}^{-1}$. Ako masu 4 atoma bakra podijelimo volumenom jedinične ćelije, dobivamo:

$$
\begin{aligned}
\rho(\mathrm{Cu}) & =\frac{m}{V}=\frac{\frac{4 \cdot M(\mathrm{Cu})}{N_{\mathrm{A}}}}{a^{3}}=\frac{\frac{4 \cdot 63,55 \cdot 10^{-3} \mathrm{~kg} \mathrm{~mol}^{-1}}{6,022 \cdot 10^{23} \mathrm{~mol}^{-1}}}{\left(3,6147 \cdot 10^{-10} \mathrm{~m}\right)^{3}}= \\
& =\frac{4,221 \cdot 10^{-25} \mathrm{~kg}}{47,23 \cdot 10^{-30} \mathrm{~m}^{3}}=8937 \mathrm{~kg} \mathrm{~m}^{-3}
\end{aligned}
$$

Primjer 4. Kristalnu strukturu cezija opisujemo prostorno centriranom kockom, BCC. Izračunajte metalni radijus cezija ako je pri $20^{\circ} \mathrm{C}$ njegova gustoća $\rho(\mathrm{Cs})=1,9 \mathrm{~g} \mathrm{~cm}^{-3}$.

\section{Rješenje}

Jedinična ćelija cezija (BCC struktura, slika 3) sadržava 2 atoma. Za volumen kocke koja sadržava 2 atoma cezija dobivamo:

$$
\begin{gathered}
V(2 \mathrm{Cs})=\frac{2 M(\mathrm{Cs}) / \mathrm{N}_{\mathrm{A}}}{\rho(\mathrm{Cs})} \\
V(2 \mathrm{Cs})=\frac{\frac{2 \cdot 132,9 \mathrm{~g} \mathrm{~mol}^{-1}}{6,022 \cdot 10^{23} \mathrm{~mol}^{-1}}}{1,9 \mathrm{~g} \mathrm{~cm}^{-3}}=232 \cdot 10^{-24} \mathrm{~cm}^{3}
\end{gathered}
$$

Odavde proizlazi da je brid jedinične ćelije cezija:

$$
a=\sqrt[3]{232 \cdot 10^{-24} \mathrm{~cm}^{3}}=6,145 \cdot 10^{-8} \mathrm{~cm}=614,5 \mathrm{pm}
$$

Za metalni radijus atoma cezija, $r(\alpha \mathrm{Cs})$, dobivamo:

$r(\mathrm{Cs})=\frac{\mathrm{a} \sqrt{3}}{4}=\frac{614,5 \cdot 10^{-8} \mathrm{~cm} \cdot \sqrt{3}}{4}=2,66 \cdot 10^{-8} \mathrm{~cm} \approx 266 \mathrm{pm}$

Dobivena vrijednost za metalni radijus cezija približno je jednaka vrijednostima koje možemo naći u tablicama atomskih radijusa.

Primjer 5. Metodom rendgenske strukturne analize nađeno je da nepoznati metal ima BCC strukturu i brid jedinične ćelije a(metal) $=330,13$ pm. Gustoća metala je $16,69 \mathrm{~g} \mathrm{~cm}^{-3}$. Izračunajte njegovu molnu masu. Koji je to metal? 


\section{Rješenje}

Kako je $m=V \cdot \rho$, proizlazi da je masa jedinične ćelije nepoznatog metala:

$$
m(\text { jed. ćelije })=a^{3} \cdot \rho=\left(3,3013 \cdot 10^{-10} \mathrm{~m}\right)^{3} \cdot 16690 \mathrm{~kg} \mathrm{~m}^{-3}
$$

Jedinična ćelija sadržava 2 atoma, pa za molnu masu dobivamo:

$$
\begin{aligned}
& M(\text { metal })=\frac{N_{\mathrm{A}} \cdot \mathrm{a}^{3} \cdot \rho}{2}= \\
& =\frac{6,022 \cdot 10^{23} \mathrm{~mol}^{-1} \cdot\left(3,3013 \cdot 10^{-10} \mathrm{~m}\right)^{3} \cdot 16690 \mathrm{~kg} \mathrm{~m}^{-3}}{2} \\
& M(\text { metal })=0,1808 \mathrm{~kg} \mathrm{~mol}^{-1}=180,8 \mathrm{~g} \mathrm{~mol}^{-1}
\end{aligned}
$$

Na osnovi tablice relativnih atomskih masa proizlazi da je riječ o tantalu.

\section{Ionski radijusi}

Godine 1913. britanski fizičar William Lawrence Bragg (1890. - 1971.), metodom difrakcije rendgenskih zraka odredio je kristalnu strukturu natrijeva klorida i drugih alkalijskih halogenida. U kristalu natrijeva klorida izmjenjuju se ioni natrija i klora tako da je svaki kation na jednakoj udaljenosti okružen sa šest aniona i obrnuto. Odredio je i razmak između iona $\mathrm{Na}^{+} \mathrm{i} \mathrm{Cl}^{-}, \approx 280 \mathrm{pm}$, ali nije mogao odrediti njihove ionske radijuse, tj. koliki dio tog razmaka pripada ionu $\mathrm{Na}^{+}$, a koliko ionu $\mathrm{Cl}^{-}$.
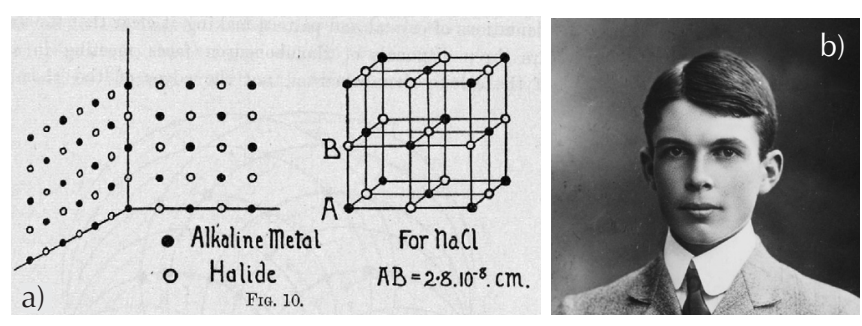

Slika 4 -a) Kristalna struktura natrijeva klorida. b) William Lawrence Bragg

Fig. 4 - a) Crystal structure of sodium chloride. b) William Lawrence Bragg

Njemačko-američki fizičar Alfred Landé (1888. - 1976.) procijenio je ionske radijuse razmatrajući dimenzije jediničnih ćelija kristalnih struktura u kojima je anion znatno veći od kationa, kao što je u litijevu jodidu. Zaključio je da je ionski radijus jodidnog iona, $r\left(I^{-}\right)=214 \mathrm{pm}$. Tom se vrijednosti koristio za određivanje radijusa drugih iona.

Mi ćemo se poslužiti istom metodom te u sljedećim primjerima pokušati odrediti radijus iona $\mathrm{Cl}^{-} \mathrm{i}$ radijuse iona alkalijskih metala.
Primjer 6. Litijev klorid ima FCC kristalnu strukturu. Od svih alkalijskih kationa litij ima najmanji ionski radijus. Pretpostavimo da se ioni klora u FCC strukturi dotiču smjerom plošne dijagonale kocke kao na slici 5. Izračunajte ionski radijus klora ako je gustoća litijeva klorida, $\rho(\mathrm{LiCl})=2,068 \mathrm{~g} \mathrm{~cm}^{-3}$.

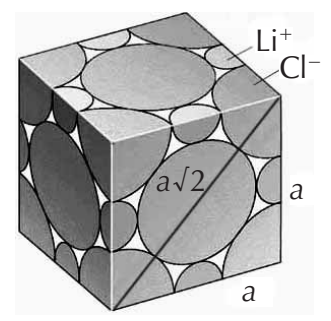

Slika 5 - Jedinična ćelija kristalne strukture litijeva klorida. Ioni klora, $\mathrm{Cl}^{-}$, dotiču se smjerom plošne dijagonale kocke.

Fig. 5 - Unit cell of the crystal structure of lithium chloride. The chlorine ions, $\mathrm{Cl}^{-}$, are assumed to touch along face diagonals.

Rješenje

Gustoća tvari jednaka je omjeru mase i volumena. Jedinična ćelija litijeva klorida (FCC struktura) sadržava 4 formulske jedinke $\mathrm{LiCl}$, pa vrijedi:

$$
\rho(\mathrm{LiCl})=\frac{m(4 \mathrm{LiCl})}{V(4 \mathrm{LiCl})}=\frac{\frac{4 \cdot M(\mathrm{LiCl})}{N_{\mathrm{A}}}}{V(4 \mathrm{LiCl})}
$$

Odavde proizlazi:

$$
\begin{aligned}
V(4 \mathrm{LiCl})= & \frac{m(4 \mathrm{LiCl})}{\rho(\mathrm{LiCl})}=\frac{\frac{4 \cdot M(\mathrm{LiCl})}{N_{\mathrm{A}}}}{\rho(\mathrm{LiCl})}= \\
= & \frac{\frac{4 \cdot 42,39 \mathrm{~g} \mathrm{~mol}^{-1}}{6,022 \cdot 10^{23} \mathrm{~mol}^{-1}}}{2,068 \mathrm{~g} \mathrm{~cm}^{-3}}=1,3615 \cdot 10^{-22} \mathrm{~cm}^{3}
\end{aligned}
$$

Za brid jedinične ćelije litijeva klorida, a( $\mathrm{LiCl})$, dobivamo:

$$
\begin{aligned}
a(\mathrm{LiCl}) & =\sqrt[3]{V(4 \mathrm{LiCl})}=\sqrt[3]{1,3615 \cdot 10^{-22} \mathrm{~cm}^{3}}= \\
& =5,144 \cdot 10^{-8} \mathrm{~cm}=514,4 \mathrm{pm}
\end{aligned}
$$

Ako se ioni $\mathrm{Cl}^{-}$dotiču smjerom plošne dijagonale kocke, slijedi:

$$
r\left(\mathrm{Cl}^{-}\right)=\frac{514,4 \mathrm{pm} \cdot \sqrt{2}}{4} \approx 182 \mathrm{pm}
$$

Rezultat se dobro slaže s vrijednošću ionskog radijusa klora u većini tablica, primjerice u Database of ionic radii. ${ }^{12,13}$

Ionski radijusi aniona uvijek su veći, a kationa uvijek manji od radijusa njihovih atoma. ${ }^{10} \mathrm{U}$ ionskim spojevima kationi 

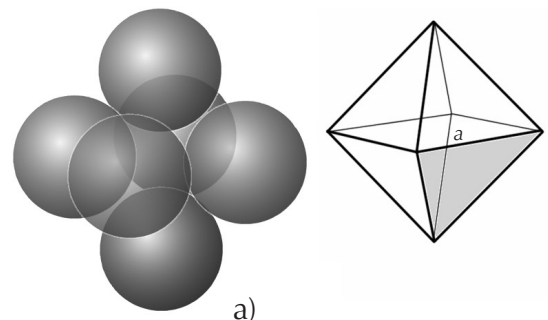

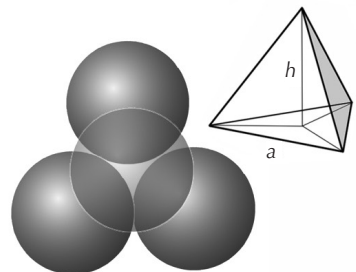

b)

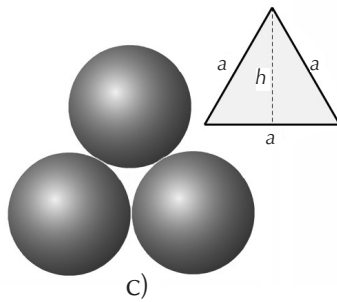

C)

Slika 6 - Šupljine u FCC gustoj slagalini kuglica jednake veličine: a) oktaedarska šupljina, b) tetraedarska šupljina, c) trokutna šupljina

Fig. 6 - Holes in a face-centered cubic lattice: a) octahedral hole, b) tetrahedral hole, c) trigonal hole

se obično smještaju u šupljine koje tvore veliki anioni, te tako neutraliziraju njihov negativni električni naboj. U FCC i HCP slagalinama postoje tri vrste takvih šupljina: oktaedarska, tetraedarska i trokutna, prikazanih na slici 6.

Primjer 7. U strukturi litijeva klorida ioni $\mathrm{Cl}^{-}$čine oktaedar, a u oktaedarskoj šupljini nalazi se ion $\mathrm{Li}^{+}$. a) Izračunajte idealan omjer radijusa kationa $r(\mathrm{~K})$ i aniona $R(\mathrm{~A})$ ako se anioni dodiruju. b) Izračunajte $r\left(\mathrm{Li}^{+}\right)$ako je $r\left(\mathrm{Cl}^{-}\right)=182 \mathrm{pm}$, kao što smo izračunali u primjeru 6.

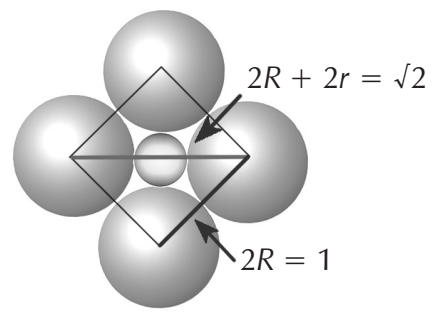

Slika 7 - Geometrija oktaedarske šupljine

Fig. 7 - Octahedral hole geometry

\section{Rješenje}

U kubnoj gustoj slagalini oktaedarske šupljine nalaze se u središtu kocke i na raspolovnicama bridova.

a) Ekvatorijalni presjek oktaedra, u kojem se anioni $R(\mathrm{~A})$ dodiruju, čini kvadrat. Uzmemo li da je $2 R(\mathrm{~A})=1$, tad je dijagonala kvadrata jednaka zbroju radijusa aniona i kationa:

$$
2 R(\mathrm{~A})+2 r(\mathrm{~K})=2 R(\mathrm{~A}) \cdot \sqrt{ } 2
$$

Podijelimo ovu jednadžbu s $2 R(\mathrm{~A})$, pa dobivamo:

$$
1+\frac{r(\mathrm{~K})}{R(\mathrm{~A})}=\sqrt{2}
$$

$$
r(\mathrm{~K}) / R(\mathrm{~A})=\sqrt{2}-1=0,41
$$

b) Iz gornjeg izraza slijedi:

$$
r\left(\mathrm{Li}^{+}\right)=R\left(\mathrm{Cl}^{-}\right) \cdot 0,41=182 \mathrm{pm} \cdot 0,41=74,6 \mathrm{pm}
$$

Dobiveni rezultat dobro se slaže s podatkom iz tablice ionskih radijusa, ${ }^{12,13}$ gdje se za $\mathrm{KB}=6$ navodi se da je $r\left(\mathrm{Li}^{+}\right)=76 \mathrm{pm}$

Na temelju znanja iz geometrije, stečenog još u osnovnoj školi, učenici mogu sami izračunati omjer radijusa kationa i aniona koji ulaze $u$ tetraedarske $i$ trokutne šupljine. ${ }^{13}$

Primjer 8. Litijev, natrijev i kalijev i rubidijev klorid imaju FCC strukturu. Difrakcijom rendgenskih zraka određeni su parametri jediničnih ćelija: $a(\mathrm{NaCl})=564 \mathrm{pm}$, $a(\mathrm{KCl})=629 \mathrm{pm}$ te $a(\mathrm{RbCl})=658,1 \mathrm{pm} \cdot{ }^{14} \mathrm{Na}$ temelju ionskog radijusa iona $\mathrm{Cl}^{-}$, određenog u primjeru 6 izračunajte ionska radijuse iona $\mathrm{Na}^{+}, \mathrm{K}^{+} \mathrm{i} \mathrm{Rb}^{+}$.

\section{Rješenje}

Natrijevi, kalijevi i rubidijevi ioni veći su od litijevih i zato se u njihovim kristalnim strukturama kloridni ioni međusobno ne dotiču. Kao što se vidi sa slike 4, duljina brida jedinične ćelije jest:

$$
a(\mathrm{NaCl})=2 r\left(\mathrm{Cl}^{-}\right)+2 r\left(\mathrm{Na}^{+}\right)
$$

pa slijedi:

$$
\begin{aligned}
& r\left(\mathrm{Na}^{+}\right)=\frac{a(\mathrm{NaCl})-2 r\left(\mathrm{Cl}^{-}\right)}{2}=\frac{564 \mathrm{pm}-2 \cdot 182 \mathrm{pm}}{2} \approx 100 \mathrm{pm} \\
& r\left(\mathrm{~K}^{+}\right)=\frac{a(\mathrm{KCl})-2 r\left(\mathrm{Cl}^{-}\right)}{2}=\frac{629 \mathrm{pm}-2 \cdot 182 \mathrm{pm}}{2} \approx 133 \mathrm{pm} \\
& r\left(\mathrm{Rb}^{+}\right)=\frac{a(\mathrm{RbCl})-2 r\left(\mathrm{Cl}^{-}\right)}{2}=\frac{658,1 \mathrm{pm}-2 \cdot 182 \mathrm{pm}}{2} \approx 147 \mathrm{pm}
\end{aligned}
$$


Dobiveni rezultati dobro se slažu s podatcima ionskih radijusa za $K B=6$ u većini tablica. Valja napomenuti da se u tablicama navode srednje vrijednosti ionskih radijusa dobivene kristalografskim istraživanjima većeg broja kristalnih struktura različitih ionskih spojeva.

U cezijevu kloridu ion $\mathrm{Cs}^{+}$okružen je s 8 iona klora, pa je koordinacijski broj cezija 8. Što je radijus kationa veći to se može okružiti većim brojem aniona, što pridonosi većoj gustoći pakiranja. Pritom raste energija vezanja sustava, pa je stoga struktura stabilnija. Kristalna struktura $\mathrm{CsCl}$ je kubna primitivna, što znači da se anioni nalaze na vrhovima, a kationi u središtu kocke, ili obratno. Upamtite da to nije BCC struktura kao kod alfa-željeza jer u BCC strukturi istovrsni atomi zauzimaju vrhove i središte kocke. U strukturi $\mathrm{CsCl}$ jedna vrsta iona zauzima vrhove, a druga središte kocke. U sljedećem primjeru izračunat ćemo ionski radijus cezija te usporediti s literaturnim podatcima. ${ }^{12,13}$

Primjer 9. Izračunajte ionski radijus $\mathrm{Cs}^{+} \mathrm{u} \mathrm{CsCl}$ ako je ionski radijus klora, $R\left(\mathrm{Cl}^{-}\right)=182 \mathrm{pm}$, kao u primjeru 6. Rendgenskom strukturnom analizom određeni su parametri jedinične ćelije $\mathrm{a}(\mathrm{CsCl})=411,9 \mathrm{pm}$.

\section{Rješenje}

$U$ strukturi cezijeva klorida ioni $\mathrm{Cl}^{-}$i $\mathrm{Cs}^{+}$dotiču se smjerom prostorne dijagonale kocke. Uzmemo li da je $\mathrm{a}(\mathrm{CsCl})=411,9 \mathrm{pm}$, tad je prostorna dijagonala kocke:

$$
\begin{gathered}
d=\mathrm{a} \sqrt{3}=411,9 \mathrm{pm} \cdot \sqrt{3} \\
2 R\left(\mathrm{Cl}^{-}\right)+2 r\left(\mathrm{Cs}^{+}\right)=713,4 \mathrm{pm}
\end{gathered}
$$

Kako je $2 R\left(\mathrm{Cl}^{-}\right)=364 \mathrm{pm}$, slijedi

$$
\begin{gathered}
2 r\left(\mathrm{Cs}^{+}\right)=713,4 \mathrm{pm}-364 \mathrm{pm}=349,4 \mathrm{pm} \\
r\left(\mathrm{Cs}^{+}\right)=349,4 \mathrm{pm} \div 2 \approx 175 \mathrm{pm}
\end{gathered}
$$

Ionski radijus cezija je približno 175 pm, što se dobro slaže s vrijednošću od 174 pm za KB $=8$ u Database of lonic Radii. ${ }^{12}$

Preostalo nam je još pokazati da se ionski radijusi kationa smanjuju porastom njihova pozitivnog naboja, tj. slijeva nadesno u periodnom sustavu elemenata.

Primjer 10. Magnezijev oksid, $\mathrm{MgO}$, ima $\mathrm{NaCl}$ kristalnu strukturu s bridom jedinične ćelije $a=421,6$ pm. Uzmite da je ionski radijus kisika, $R\left(\mathrm{O}^{2-}\right)=140 \mathrm{pm}$. Izračunajte ionski radijus magnezija. $U$ strukturi magnezijeva oksida kisikovi ioni se ne dotiču.

\section{Rješenje}

Kao što se vidi sa slike 5, brid jedinične ćelije magnezijeva oksida jest:

$$
\mathrm{a}(\mathrm{MgO})=2 R\left(\mathrm{O}^{2-}\right)+2 r\left(\mathrm{Mg}^{2+}\right)
$$

pa slijedi

$r\left(\mathrm{Mg}^{2+}\right)=\frac{a(\mathrm{MgO})-2 R\left(\mathrm{O}^{2-}\right)}{2}=\frac{421,6 \mathrm{pm}-280 \mathrm{pm}}{2}=70,8 \mathrm{pm}$

Pokazali smo da je ionski radijus magnezija manji od ionskog radijusa natrija, pa očekujemo da je ionski radijus aluminija još manji. U tablicama ionskih radijusa navodi se da je $r\left(\mathrm{Al}^{3+}\right)=54 \mathrm{pm}$. Ioni $\mathrm{Na}^{+}, \mathrm{Mg}^{2+}$ i $\mathrm{Al}^{3+}$ su izoelektronski, tj. sadržavaju jednak broj elektrona. Atomska jezgra većeg pozitivnog naboja jače privlači jednak broj elektrona i zato su radijusi iona druge skupine manji od radijusa iona prve skupine periodnog sustava elemenata.

Kalcijev, stroncijev i barijev oksid također imaju kristalnu strukturu tipa $\mathrm{NaCl}$. Učenici mogu sami na internetu pronaći gustoće $\mathrm{CaO}, \mathrm{SrO}$ i $\mathrm{BaO}$, izračunati bridove jediničnih ćelija te ionske radijuse iona $\mathrm{Ca}^{2+}, \mathrm{Sr}^{2+}$ i $\mathrm{Ba}^{2+}$, uzimajući da je $R\left(\mathrm{O}^{2-}\right)=140 \mathrm{pm}$. Dobivene rezultate mogu usporediti $\mathrm{s}$ ionskim radijusima izoelektronskih iona $\mathrm{K}^{+}, \mathrm{Rb}^{+} \mathrm{i} \mathrm{Cs}^{+}$.

\section{Zaključak}

Do spoznaja o veličini atoma $\mathrm{i}$ iona učenici mogu sami doći rješavanjem primjerenih zadataka. Za to im je dostatno znanje iz matematike i geometrije stečeno u osnovnoj školi. Rješavanjem zadataka učenici samostalno spoznaju da se atomski $\mathrm{i}$ ionski radijusi atoma kemijskih elemenata u skupinama periodnog sustava povećavaju odozgo prema dolje, što inače u predavačkoj nastavi moraju naučiti napamet. Slaganjem kuglica jednake veličine upoznaju kristalne strukture tehnički važnih metala. Rješavanjem zadataka dolaze do spoznaje da su ionski spojevi guste slagaline aniona i kationa te da je radijus kationa manji, a aniona uvijek veći od radijusa pripadnih atoma. Razumiju da se u kristalnoj strukturi kation većeg radijusa okružuje većim brojem aniona jer to pridonosi većoj gustoći pakiranja. Pritom raste energija vezanja sustava, pa je stoga struktura stabilnija. $\mathrm{Na}$ temelju riješenih primjera učenici sami uviđaju da se ionski radijusi kationa smanjuju porastom njihova pozitivnog naboja, tj. slijeva nadesno u periodnom sustavu elemenata. U predavački orijentiranoj nastavi učenici "znanje" stječu memoriranjem i reproduciranjem naučenog. $U$ problemski orijentiranoj nastavi učenici znanje i vještine stječu vlastitom aktivnošću. 


\section{Literatura}

\section{References}

1. URL: https://edutorij.e-skole.hr/share/proxy/alfresco-noauth/edutorij/api/proxy-guest/4874fe79-8302-4ea2-b5164657ea249026/kemija-7/m03/j01/index.html (10. 8. 2020.).

2. V. Lopac, Kilogram i mol u novome ruhu - o korjenitim promjenama u Međunarodnom sustavu jedinica (SI), Kem. Ind. 69 (7-8) (2020) 407-414, doi: https://doi.org/10.15255/ KUI.2019.060.

3. D. Grdenić, Molekule i kristali, Školska knjiga, Zagreb 2005., str. 397.

4. URL: https://hr.wikipedia.org/wiki/John_Dalton (10. 8. 2020.).

5. URL: https://en.wikipedia.org/wiki/Johannes_Kepler (10.8. 2020.).

6. D. Grdenić, Molekule i kristali, Školska knjiga, Zagreb 2005. str. 389-395.
7. URL: https://en.wikipedia.org/wiki/Periodic_table_(crystal_ structure) (10. 8. 2020.).

8. URL: https://www.webelements.com/iron/crystal_structure. html (10. 8. 2020.).

9. URL: https://www.slideshare.net/ilyashussain6/metallurgical-structures (10. 8. 2020.).

10. D. Grdenić, Molekule i kristali, Školska knjiga, Zagreb 2005., str. 253-262.

11. D. Grdenić, Molekule i kristali, Školska knjiga, Zagreb 2005., str. 260.

12. URL: http://abulafia.mt.ic.ac.uk/shannon/ptable.php (10. 8. 2020.).

13. URL: https://www.chemguide.co.uk/atoms/properties/atradius.html (10. 8. 2020.)

14. URL: https://www.korth.de/index.php/162/items/30.html (10. 8. 2020.).

\section{SUMMARY \\ How to Acquire an Idea of the Size of Atoms and lons \\ Milan Sikirica}

Chemistry teaching uses quantities such as the picometer and Avogadro number. Teachers easily pronounce or write, and students learn to reproduce these quantities by heart, without any idea of how much numbers like $10^{-12}$ or $10^{23}$ actually are. This paper shows how students can, by solving simple problems, learn independently about the size of atoms and the meaning of Avogadro's number. In the present digital age, "distance learning" and digitised textbooks, modern school does not need standard "classes" but laboratories, workshops, sports halls, and sports fields, where students could acquire knowledge, skills, and abilities by exerting their activities.

\section{Keywords}

Chemistry education, HCP and FCC crystal structures, atomic and ionic radii, interstitial holes, solved exercise questions

Division of General and Inorganic Chemistry

Department of Chemistry Faculty of Science, University of Zagreb Horvatovac 102a

10000 Zagreb, Croatia
Professional paper

Received August 19, 2020 Accepted September 26, 2020 